\title{
Increase of nutrients export and production of pitaya whit potassium fertilization
}

\author{
Josimara Mendes Rabelo ${ }^{\circledR}$, Maria do Céu Monteiro Cruz ${ }^{*}{ }^{\circledR}$, Nubia Cassiana Santos ${ }^{\circledR}$, \\ Deilson de Almeida Alves ${ }^{\circledR}$, João Esdras Lima ${ }^{\circledR}$, Enilson de Barros Silva ${ }^{\circledR}$
}

Federal University of Jequitinhonha and Mucuri Valleys, Diamantina, Brazil *Corresponding author, e-mail: mariceu@ufvjm.edu.br

\begin{abstract}
Characterization works of pitayas show that the potassium $(K)$ is the nutrient most exported, thus, influences in the productivity and quality of this fruit. However, these researches do not report the nutrients export by pitaya's associating the fertilization carried out in the orchard, information that is relevant to make the nutrients reposition adequate at the time of fertilization. The research was carried out to evaluate the supply of $\mathrm{K}_{2} \mathrm{O}$ in the export of nutrients and productivity of the Hylocereus undatus and Hylocereus polyrhizus pitaya species. The analysis was carried out in the mature fruits harvested in two harvests. Potassium fertilization was performed at doses of $0 ; 50 ; 100$ and $200 \mathrm{~g}$ of $\mathrm{K}_{2} \mathrm{O}$ per plant. Nutrient export per ton of fruit was calculated from the determination of the nutrient levels and the dry matter of the pitaya pulp. The export of nutrients by the pitaya of the species $\mathrm{H}$. undatus and $\mathrm{H}$. polyrhizus occurs in the following order: $\mathrm{K}>\mathrm{N}>\mathrm{P}>\mathrm{Ca}>\mathrm{Mg}>$ and $\mathrm{Mn}>\mathrm{Fe}>\mathrm{Cu}>\mathrm{Zn}>\mathrm{B}$. These species of pitaya have similar nutritional requirements, enabling them to be receive same fertilization management. The amount of nutrients exported was higher in plants fertilized with potassium due to the higher productivity achieved. Orchards of pitaya that reach high productivity require a greater quantity of nutrients, due to the increase export by the fruits.
\end{abstract}

Keywords: Hylocereus undatus, Hylocereus polyrhizus, mineral composition, productivity

\section{Introduction}

The pitaya species belongs to the cacti family. Cacti are considered rustic plants because they adapt to different climatic and soil conditions, requiring producers to use only limited technology to produce fruit. Data on pitaya's fertilization needs are scarce, compared to other tropical fruit species in the world, so its precise demand for various mineral nutrients is unknown for all producing countries (Mizrahi, 2014).

Due to the lack of this information, specifically in Brazil, management has been carried out differently wherever this species is cultivated, resulting in varying levels of productivity, entre 2 to 9 tons per hectare (Moreira et al., 2012; Fernandes et al., 2018). However, mineral fertilization is critical, especially when the annual yields of pitaya orchards are high (between 20 to 45 tons per hectare). Evidence supporting the need for fertilization has recently been demonstrated through the work of
Nobel and De la Barrera (2002), Weiss et al. (2009), and Fernandes et al. (2018), who tested the effects of mineral application.

Initial research conducted in Brazil highlighted the characteristics of the pitaya that are attractive to consumers, due the pitaya pulp has a high moisture content and a low-calorie value; the predominant fatty acid is linoleic acid; it has a high antioxidant potential; and the chemical properties of pitaya fruit can help maintain a healthy diet (Jerônimo et al., 2015). Among the highlighted minerals is potassium (K) (Cordeiro et al., 2015), which increased demand in the country's largest commercial centers and generated the interest of new producers.

$K$ is understood to be the macronutrient that contributes most to the improvement of fruit quality. It is fundamental in metabolic processes, such as the synthesis of proteins and sugars and is responsible for 
transporting sugars and carbohydrates produced by photosynthesis to storage organs, such as fruits (IPI, 2013). Plants properly fertilized with $\mathrm{K}$ produce pitayas with a better appearance and flavor, and higher productivity (Fernandes et al., 2018).

Therefore, it is fundamental to identify the amount of nutrients exported by the fruit to support fertilization, aiming to replace mineral nutrients in the soil to increase the area under cultivation and increase the productivity of commercial-quality pitaya.

In this context, the present study was carried out to evaluate potassium fertilization in the export of nutrients and fruits production of the Hylocereus undatus and Hylocereus polyrhizus pitaya species.

\section{Material and Methods}

The fruits of the pitaya species Hylocereus undatus (Haw.) Britton \& Rose and Hylocereus polyrhizus (Web.) Britton \& Rose evaluated were harvested in the third and fourth productive cycle, 2015/2016 and 2016/2017 harvests, of an orchard located at $18^{\circ} 04^{\prime} 15^{\prime \prime}$ ' latitude and $43^{\circ} 28^{\prime} 15^{\prime \prime} \mathrm{W}$ longitude, at 726 meters above sea level, implanted in 2012.

The region has an Aw climate type, classified as high-altitude tropical, according to the classification of Koppen. Observation data in the experimental area during the evaluation period recorded average temperatures of $34.8^{\circ} \mathrm{C}$ maximum and $19.2^{\circ} \mathrm{C}$ minimum in spring, $35.1{ }^{\circ} \mathrm{C}$ maximum, and $21.5^{\circ} \mathrm{C}$ minimum in the summer; $27.6{ }^{\circ} \mathrm{C}$ maximum and $17.8^{\circ} \mathrm{C}$ minimum in autumn and $26.8^{\circ} \mathrm{C}$ maximum and $14.3^{\circ} \mathrm{C}$ minimum in winter. The winter is dry and it rains in the summer with an average annual rainfall of 1,246 $\mathrm{mm}$.

The soil of the area is classified as Yellow Dystrophic Latosol, with $60 \%$ of sand, $27 \%$ of clay and $13 \%$ of silt. The soil analysis performed in June, 2015, prior to the start of fertilization showed the following characteristics: $\mathrm{pH}=4.1$; $\mathrm{P}=52.3 \mathrm{mg} \mathrm{dm}^{-3} ; \mathrm{K}=40.7 \mathrm{mg} \mathrm{dm}^{-3} ; \mathrm{Ca}=1.2 \mathrm{cmolc} \mathrm{dm}^{-3}$; $\mathrm{Mg}=0.7 \mathrm{cmolc} \mathrm{dm}^{-3} ; \mathrm{Al}=1.13 \mathrm{cmolc} \mathrm{dm}^{-3} ;$ organic matter $=0.4 \mathrm{dag} \mathrm{kg}^{-1}$; base saturation $(\mathrm{V})=25 \%$ and $\mathrm{T}$ : cation exchange capacity at $\mathrm{pH} 7.0=5.1 \mathrm{cmolc} \mathrm{dm}^{-3}$.

Correction and fertilization of the soil before planting were carried out according to the result of the chemical analysis, to raise base saturation to $60 \%$. For the fertilization, $10 \mathrm{~L}$ of bovine manure and $54 \mathrm{~g}$ of $\mathrm{P}$ per hole applied.

For the planting of pitaya orchards, the incorporation of bovine manure is important for the development of the root system, especially in soils with a low content of organic matter. The source used and the amount added in planting of the studied orchard provided $23.8 \mathrm{~g}$ of $\mathrm{N}, 6.6 \mathrm{~g}$ of $\mathrm{P}$ and $39.5 \mathrm{~g}$ of $\mathrm{K}$ per hole.

Ten-month-old the plants of the species two, obtained from the rooting of cuttings were planted in hole of of $0.5 \times 0.5 \times 0.5 \mathrm{~m}$. Irrigation was performed, providing $20 \mathrm{~L}$ of water per plant weekly, after planting, and during fertilization times. Weed control was carried out by hand weeding up to $40 \mathrm{~cm}$ from the plant stem and mowing between lines

Plants were conducted over eucalyptus posts, installed at $1.80 \mathrm{~m}$ in height of soil which contained a $1 \mathrm{~m}$ long beam was positioned at the top of the post, forming a "T"-shaped structure. The plants were pruned leaving only cladode main to reach the desired height; they were later pruned to form the productive shoots.

The experimental design was randomized blocks, with a $2 \times 4$ factorial design. The factors were two pitaya species and four doses of $\mathrm{K}_{2} \mathrm{O}: 0,50,100$, and $200 \mathrm{~g}$ per plant, with four blocks and three plants per plot.

The additional fertilization was done applying $100 \mathrm{~g}$ of $\mathrm{N}$ and $30 \mathrm{~g}$ of $\mathrm{P}$ per plant. The $\mathrm{N}$ and $\mathrm{K}$ were divided in three epochs, starting from the pre-flowering of the plants, at 60 and 120 days after the beginning of the flowering; and the $\mathrm{P}$ applied in the third plot of the fertilization. The source of $\mathrm{K}$ used was potassium chloride.

Cleaning pruning was performed to eliminate shoots attacked by pests and pathogens, especially in plants that did not receive potassium fertilization.

The pitayas were harvested from December to April, when the fruit's red color matched that of the bark, when they reach full maturity. The yield per plant was then evaluated, and samples were taken from each fertilization to determine the nutrient levels.

In the two harvests studied, which were the third and fourth cycle of the orchard's production, productivity was determined by the mass of fruits harvested per plant during the entire harvest period, and the density of planting in the area, of 1,111 plants per hectare.

Pulp samples from the pitayas were collected to represent each plot, being composed of 40 fruits per fertilization for each harvest period. The samples were placed in a Petri dish and taken to a forced circulation oven set at $65^{\circ} \mathrm{C}$ until a constant mass was reached. Subsequently, the dry pulp was stored in plastic pots for analysis of nutrient levels. All analyses were performed in triplicate.

The pulp dry matter samples were exposed to nitric-perchloric digestion for the determination of phosphorus (P), sulfur (S) and boron (B) levels via colorimetry and potassium $(K)$ via flame photometry. Total nitrogen 
(N) was determined by the Kjeldhal method, after sulfuric digestion. The calcium (Ca), magnesium (Mg), zinc (Zn), iron (Fe), copper ( $\mathrm{Cu}$ ) and manganese (Mn) levels were determined by atomic absorption spectrophotometry (Malavolta et al., 1997).

Nutrient export was calculated based on the nutrient levels and the dry matter of the fruits, interpreting plant productivity as a function of potassium fertilization.

The data was analyzed using an analysis of variance. The variables with significant differences between the doses of $\mathrm{K}_{2} \mathrm{O}$ tested were submitted to a regression analysis, using a t-test and $p<0.05$. To calculate the nutrient levels and export in the regression equations adjusted for $\mathrm{K}_{2} \mathrm{O}$ doses, the $\mathrm{K}$ dose that provided the highest fruit productivity in the two harvests evaluated was used.

\section{Results and Discussion}

Potassium fertilization increased the productivity of $\mathrm{H}$. undatus from 5.65 t ha-1 to $8.7+\mathrm{ha}^{-1}$ and from $1.21 \mathrm{t} \mathrm{ha}^{-1}$ to $7.5 \mathrm{tha}^{-1}$ with $200 \mathrm{~g}$ of $\mathrm{K}_{2} \mathrm{O}$ and $160 \mathrm{~g}$ of $\mathrm{K}_{2} \mathrm{O}$ applied per plant in the third and fourth production cycles, respectively (Table 1). In H. polyrhizus, productivity increased from $6.35 \mathrm{tha}^{-1}$ to $7.9 \mathrm{th}^{-1}$ and from $2.11 \mathrm{th}^{-1}$ to $7.9 \mathrm{tha}^{-1}$ (Table 2) with the application of $200 \mathrm{~g}$ of $\mathrm{K}_{2} \mathrm{O}$ per plant.

These results demonstrate that the two pitaya species responded well to fertilization, as the plants that did not receive the potassium fertilization were less productive, especially in the fourth year of the orchard's production (Tables 2 and 3). This suggests that there was an exhaustion of $K$ reserves in plants, reduced the productivity.

In soils with low K availability, nutrient supply through fertilization is necessary to provide the plants with the quantities required for growth and production, since this nutrient performs several essential functions such as assimilation, storage of assimilates and the improvement of fruit quality (IPI, 2013). In addition, adjusting fertilization will contribute to all of the fruits meeting the standard for commercialization, as this will enable growers to achieve high levels of productivity and quality.

It has been reported by other authors that mineral fertilization in pitaya orchards can increase productivity when combined with fertilizers and sources. In an orchard of $H$. polyrhizus in Bangladesh, productivity increased from 12.88 tha $^{-1}$ to $31.64 \mathrm{tha}^{-1}$, with the application of 250 $\mathrm{g}$ of $\mathrm{K}_{2} \mathrm{O}$ per plant, which is the equivalent of $540 \mathrm{~g}$ of $\mathrm{N}$, $310 \mathrm{~g}$ of $\mathrm{P}$ (Chakma et al., 2014). In Brazil, the increase in productivity was $3.7+\mathrm{ha}^{-1} \mathrm{t}$ due to potassium fertilization

Table 1. Regression equations and determination coefficient $\left(R^{2}\right)$ for the nutrient levels $N, K, P, C a$ and $M g(g ~ k g-1), B, C u, Z n$, $\mathrm{Fe}$ and $\mathrm{Mn}\left(\mathrm{mg} \mathrm{kg}^{-1}\right)$ in pitayas of the species Hylocereus undatus and Hylocereus polyrhizus as a function of the doses of $\mathrm{K}_{2} \mathrm{O}$, in the third and fourth production cycles.

\begin{tabular}{|c|c|c|c|c|c|c|}
\hline \multirow{2}{*}{ Nutrient } & \multicolumn{4}{|c|}{ H. undatus } & \multicolumn{2}{|c|}{ polyrhizus } \\
\hline & Equation & $R^{2}$ & Level & Equation & $R^{2}$ & Level \\
\hline \multicolumn{7}{|c|}{ third cycle of production } \\
\hline $\mathrm{N}$ & $\hat{Y}=14.68^{\text {ns }}$ & - & 14.68 & $\hat{Y}=10.65^{\text {ns }}$ & - & 10.65 \\
\hline$P$ & $\hat{Y}=1.67^{\mathrm{ns}}$ & - & 1.67 & $\hat{Y}=1.23^{\text {ns }}$ & - & 1.23 \\
\hline K & $\hat{Y}=12.4875+0.018721 x^{*}$ & 98.38 & 16.23 & $\hat{Y}=10.9105+0.0182 x^{* *}$ & 82.97 & 14.55 \\
\hline $\mathrm{Ca}$ & $\hat{Y}=0.582+0.0019 x^{* *}$ & 91.58 & 0.96 & $\hat{Y}=0.658+0.0019 x^{* *}$ & 92.61 & 1.03 \\
\hline$M g$ & $\hat{Y}=0.2545+0.0025 x^{* *}$ & 96.11 & 0.75 & $\hat{Y}=0.2515+0.00116 x^{* *}$ & 92.02 & 0.48 \\
\hline B & $\hat{Y}=4.412-0.004937 x^{* *}$ & 90.96 & 3.43 & $\hat{Y}=4.225-0.013664 x^{* *}$ & 95.47 & 1.49 \\
\hline $\mathrm{Cu}$ & $\hat{Y}=20.11^{\mathrm{ns}}$ & - & 20.11 & $\hat{Y}=20.5725-0.007021 x^{* *}$ & 79.48 & 19.16 \\
\hline$M n$ & $\hat{Y}=105.65^{\mathrm{ns}}$ & - & 105.65 & $\hat{Y}=56.29^{\text {ns }}$ & - & 56.29 \\
\hline Zn & $\hat{Y}=19.682500-0.033464 x^{* *}$ & 96.51 & 12.98 & $\hat{Y}=13.8435-0.018176 x^{* *}$ & 85.51 & 10.2 \\
\hline $\mathrm{Fe}$ & $\hat{Y}=41.83^{\text {ns }}$ & - & 41.83 & $\hat{Y}=36.77^{\mathrm{ns}}$ & - & 36.77 \\
\hline Productivity $\left(t \mathrm{ha}^{-1}\right)$ & $\hat{Y}=5.6545+0.015356 x^{* *}$ & 84.27 & $8.7^{P}$ & $\hat{Y}=6.347+0.007541 x^{* *}$ & 97.7 & $7.9^{P}$ \\
\hline \multicolumn{7}{|c|}{ fourth cycle of production } \\
\hline $\mathrm{N}$ & $\hat{Y}=12.665-0.0104 x^{* *}$ & 97.48 & 11.0 & $\hat{Y}=9.5241-0.0158 x^{* *}$ & 81.55 & 6.36 \\
\hline$P$ & $\hat{Y}=1.6795-0.00568 x^{* *}$ & 97.38 & 0.77 & $\hat{Y}=1.5425-0.0039 x^{* *}$ & 88.84 & 0.76 \\
\hline K & $\hat{Y}=11.1688+0.058 x-0.000268 x^{2 * *}$ & 98.28 & 13.59 & $\hat{Y}=7.892+0.02761 x^{* *}$ & 89.6 & 13.41 \\
\hline $\mathrm{Ca}$ & $\hat{Y}=0.76^{\mathrm{ns}}$ & - & 0.76 & $\hat{Y}=0.84^{\mathrm{ns}}$ & - & 0.84 \\
\hline$M g$ & $\hat{Y}=0.24^{\mathrm{ns}}$ & - & 0.24 & $\hat{Y}=0.25^{\text {ns }}$ & - & 0.25 \\
\hline B & $\hat{Y}=3.48^{\text {ns }}$ & - & 3.48 & $\hat{Y}=3.62^{\text {ns }}$ & - & 3.62 \\
\hline $\mathrm{Cu}$ & $\hat{Y}=19.77^{n s}$ & - & 19.77 & $\hat{Y}=20.32^{\text {ns }}$ & - & 20.32 \\
\hline$M n$ & $\hat{Y}=139.9^{\text {ns }}$ & - & 139.9 & $\hat{Y}=118.28^{\text {ns }}$ & - & 118.28 \\
\hline Zn & $\hat{Y}=14.2^{\text {ns }}$ & - & 14.2 & $\hat{Y}=13.51^{\text {ns }}$ & - & 13.51 \\
\hline $\mathrm{Fe}$ & $\hat{Y}=41.1^{\mathrm{ns}}$ & - & 41.1 & $\hat{Y}=47.19^{\text {ns }}$ & - & 47.19 \\
\hline Productivity $\left(\dagger \mathrm{ha}^{-1}\right)$ & $\hat{Y}=1.215+0.079 x-0.00025 x^{2 * *}$ & 95.3 & $7.5^{\mathrm{P}}$ & $\hat{Y}=2.1105+0.02913 x^{* *}$ & 81.38 & $7.9^{P}$ \\
\hline
\end{tabular}


Table 3. Regression equations and determination coefficient $\left(R^{2}\right)$ for the export of nutrients $N, P, K$, $\mathrm{Ca}$ and $\mathrm{Mg}(\mathrm{kg}) \mathrm{B}, \mathrm{Cu}, \mathrm{Zn}, \mathrm{Mn}$ and $\mathrm{Fe}(\mathrm{g})$, according to the productivity reached by Hylocereus undatus, as a function of the doses of $\mathrm{K}_{2} \mathrm{O}$, in the third and fourth production cycles.

\begin{tabular}{|c|c|c|c|c|}
\hline Nutrient & Equation & $\mathrm{R}^{2}$ & Value $^{1}$ & Value $^{2}$ \\
\hline \multicolumn{5}{|c|}{ third cycle of production } \\
\hline $\mathrm{N}$ & $\hat{Y}=10.7745+0.03096 x^{* *}$ & 91.74 & 16.96 & 1.95 \\
\hline$P$ & $\hat{Y}=1.1935+0.00497 x^{* *}$ & 88.18 & 2.18 & 0.25 \\
\hline K & $\hat{Y}=8.4965+0.06149 x^{* *}$ & 92.93 & 20.79 & 2.39 \\
\hline $\mathrm{Ca}$ & $\hat{Y}=0.4595+0.0038 x^{* *}$ & 87.75 & 1.20 & 0.14 \\
\hline$M g$ & $Y=0.186+0.00117 x^{* *}$ & 94.61 & 0.42 & 0.05 \\
\hline B & $\hat{Y}=2.9688+0.0163 x-0.000054 x^{2 * *}$ & 97.55 & 4.1 & 0.47 \\
\hline $\mathrm{Cu}$ & $\hat{Y}=15.3525+0.0511 x^{* *}$ & 85.38 & 25.56 & 2.94 \\
\hline$M n$ & $\hat{Y}=75.0045+0.36396 x^{* *}$ & 84.03 & 147.7 & 16.98 \\
\hline Zn & $\hat{Y}=12.1627+0.1202 x-0.00049 x^{2 * *}$ & 92.93 & 16.4 & 1.89 \\
\hline $\mathrm{Fe}$ & $\hat{Y}=32.029+0.10453 x^{* *}$ & 85.67 & 52.93 & 6.08 \\
\hline Productivity $\left(\dagger \mathrm{ha}^{-1}\right)$ & $\hat{Y}=5.6545+0.015356 x^{* *}$ & 84.27 & - & - \\
\hline \multicolumn{5}{|c|}{ fourth cycle of production } \\
\hline $\mathrm{N}$ & $\hat{Y}=1.8748+0.1433 x-0.00051 x^{2 * *}$ & 98.9 & 11.8 & 1.57 \\
\hline$P$ & $\hat{Y}=0.2946+0.0179 x-0.00008 x^{2 * *}$ & 89.9 & 1.1 & 0.15 \\
\hline K & $\hat{Y}=1.5658+0.2911 x-0.00086 x^{2 * *}$ & 99.9 & 14.9 & 2 \\
\hline $\mathrm{Ca}$ & $\hat{Y}=0.1285+0.0098 x-0.000036 x^{2 * *}$ & 95.5 & 0.78 & 0.11 \\
\hline$M g$ & $\hat{Y}=0.0431+0.00334 x-0.000013 x^{2 * *}$ & 93.9 & 0.25 & 0.03 \\
\hline B & $\hat{Y}=0.5972+0.04147 x-0.00015 x^{2 * *}$ & 96.2 & 4.1 & 0.54 \\
\hline $\mathrm{Cu}$ & $\hat{Y}=2.888+0.2699 x-0.00101 x^{2 * *}$ & 98.7 & 20.8 & 2.77 \\
\hline$M n$ & $\hat{Y}=14.787+2.182 x-0.00858 x^{2 * *}$ & 99.9 & 143.6 & 19.1 \\
\hline Zn & $\hat{Y}=5.059+0.04784 x^{* *}$ & 79.7 & 12.7 & 1.69 \\
\hline $\mathrm{Fe}$ & $\hat{Y}=5.8344+0.5747 x-0.0028 x^{2 * *}$ & 99.2 & 26.1 & 3.48 \\
\hline Productivity († ha-1) & $\hat{Y}=1.215+0.079 x-0.00025 x^{2 * *}$ & 95.3 & - & - \\
\hline
\end{tabular}

Table 2. Regression equations and determination coefficient $\left(R^{2}\right)$ for the export of nutrients $N, P, K$, $\mathrm{Ca}$ and $\mathrm{Mg}(\mathrm{kg}) \mathrm{B}, \mathrm{Cu}, \mathrm{Zn}, \mathrm{Mn}$ and $\mathrm{Fe}(\mathrm{g})$, according to the productivity reached by Hylocereus polyrhizus, as a function of the doses of $\mathrm{K}_{2} \mathrm{O}$, in the third and fourth production cycles.

\begin{tabular}{|c|c|c|c|c|}
\hline Nutrient & Equation & $R^{2}$ & Value' & Value $^{2}$ \\
\hline \multicolumn{5}{|c|}{ third cycle of production } \\
\hline N & $\hat{Y}=7.7715+0.0346 x^{* *}$ & 96.45 & 14.7 & 1.88 \\
\hline$P$ & $\hat{Y}=1.039+0.00388 x^{* *}$ & 74.83 & 1.81 & 0.23 \\
\hline K & $\hat{Y}=10.5235+0.0361 x^{* *}$ & 76.19 & 17.73 & 2.27 \\
\hline $\mathrm{Ca}$ & $\hat{Y}=0.6355+0.00285 x^{*}$ & 76.84 & 1.2 & 0.15 \\
\hline $\mathrm{Mg}$ & $\hat{Y}=0.2345+0.0041 x^{*}$ & 76.06 & 1.05 & 0.13 \\
\hline B & $\hat{Y}=4.1465-0.01082 x^{*}$ & 93.09 & 6.3 & 0.81 \\
\hline $\mathrm{Cu}$ & $\hat{Y}=18.706+0.0423 x^{* *}$ & 99.59 & 27.16 & 3.48 \\
\hline$M n$ & $\hat{Y}=52.1995+0.1085 x^{* *}$ & 99.64 & 73.89 & 9.47 \\
\hline Zn & $\hat{Y}=14.6313+0.491 x-0.00025 x^{2 *}$ & 99.44 & 102.8 & 13.85 \\
\hline $\mathrm{Fe}$ & $\hat{Y}=41.57^{\text {ns }}$ & - & 41.57 & 5.33 \\
\hline Productivity $\left(\dagger \mathrm{ha}^{-1}\right)$ & & 97.7 & - & - \\
\hline \multicolumn{5}{|c|}{ fourth cycle of production } \\
\hline N & $\hat{Y}=3.319+0.029411 x^{* *}$ & 82.35 & 9.2 & 1.16 \\
\hline$P$ & $\hat{Y}=0.4485+0.00369 x^{* *}$ & 76.76 & 1.18 & 0.15 \\
\hline K & $\hat{Y}=2.5375+0.0667 x^{* *}$ & 91.11 & 15.87 & 2.0 \\
\hline $\mathrm{Ca}$ & $\hat{Y}=0.2535+0.00389 x^{* *}$ & 81.52 & 1.03 & 0.13 \\
\hline $\mathrm{Mg}$ & $\hat{Y}=0.0805+0.00127 x^{* *}$ & 79.3 & 0.85 & 0.11 \\
\hline B & $\hat{Y}=0.9565+0.0183 x^{* *}$ & 88.84 & 4.61 & 0.58 \\
\hline $\mathrm{Cu}$ & $\hat{Y}=6.4275+0.0946 x^{* *}$ & 78.64 & 25.35 & 3.2 \\
\hline$M n$ & $\hat{Y}=20.2605+0.0837 x^{* *}$ & 96.39 & 37 & 4.68 \\
\hline $\mathrm{Zn}$ & $\hat{Y}=3.6675+0.07498 x^{* *}$ & 87.64 & 18.67 & 2.35 \\
\hline $\mathrm{Fe}$ & $\hat{Y}=17.5845+0.13341 x^{* *}$ & 75.71 & 44.16 & 5.64 \\
\hline Productivity ( h ha-1) $^{-1}$ & $\hat{Y}=2.1105+0.02913 x^{* *}$ & 81.38 & - & - \\
\hline
\end{tabular}

${ }^{* *}=p<0.01,{ }^{*}=p<0.05$, "t" test; ns = not significant. Value' = amount of nutrient exported to maximum productivity of orchard pitaya. Value $^{2}=$ amount of nutrient exported per ton of pitaya produced 
(Fernandes et al., 2018). The main difference can be attributed to the planting density adopted, in Bangladesh a density of 8,000 plants per hectare was used.

In relation to nutrient levels, $\mathrm{K}$ is the mineral nutrient with the highest levels in the pulp of $\mathrm{H}$. undatus, followed by $\mathrm{N}, \mathrm{P}, \mathrm{Ca}$ and $\mathrm{Mg}$. The micronutrients were found in the following amounts: $\mathrm{Mn}>\mathrm{Fe}>\mathrm{Cu}>\mathrm{Zn}>\mathrm{B}$ (Table 1), calculated from the doses of $200 \mathrm{~g}$ of $\mathrm{K}_{2} \mathrm{O}$ in the third cycle of production and $160 \mathrm{~g}$ of $\mathrm{K}_{2} \mathrm{O}$ in the fourth production cycle, which provided the highest productivity.

Fruits of Hylocereus sp. organically cultivated in Malaysia had nutrients present in the following amounts: $\mathrm{K}>\mathrm{Mg}>\mathrm{P}>\mathrm{Ca}$ (Khalili et al., 2006); in Cordeiro et al. (2015), the nutrient levels were found to be $K>N>C a>M g>P$, in fruits of $H$. polyrhizus in northern Minas Gerais. In fruits harvested in Malaysia, the order of the levels was $\mathrm{K}>\mathrm{Mg}>\mathrm{Ca}$ (Nurul \& Asmah, 2014).

The plants of $\mathrm{H}$. undatus fertilized with $200 \mathrm{~g}$ of $\mathrm{K}_{2} \mathrm{O}$ showed a $30 \%$ increase in the $\mathrm{K}$ levels in the production cycle and $27 \%$ in the 2016/17 cycle compared to fruits harvested in plants that did not receive potassium fertilization, with levels of $16.23 \mathrm{~g} \mathrm{~kg}^{-1}$ and $14.17 \mathrm{~g} \mathrm{~kg}^{-1}$ respectively. In $\mathrm{H}$. polyrhizus, the levels of $\mathrm{K}$ increased from $10.91 \mathrm{~g} \mathrm{~kg}^{-1}$ to $14.55 \mathrm{~g} \mathrm{~kg}^{-1}$ in the third cycle and from $7.89 \mathrm{~g} \mathrm{~kg}^{-1}$ to $13.41 \mathrm{~g} \mathrm{~kg}^{-1}$ in the fourth cycle with an application of $200 \mathrm{~g}$ of $\mathrm{K}_{2} \mathrm{O}$ per plant. This corresponded to a $21 \%$ and $69 \%$ increase, respectively, compared to plants that did not receive the fertilization (Table 1).

The highest observed $\mathrm{K}$ levels can be justified because this nutrient is highly redistributed in the plant. It has the function of transporting the photoassimilates to the fruits (Ganeshamurthy et al., 2011; IPI, 2013), so the increased doses provided an increase in the levels observed in the fruits.

The higher levels of $K$ in the pitayas provide evidence that the availability of nutrients to plants through fertilization is critical to the production of fruits with a greater composition of nutrients, important for its quality.

Research in several tropical fruits shows the effects of $K$ on fruit quality (Aular \& Natale, 2013). Highlighting the maturity uniformity and the greater resistance to physical damage during transport and storage. The $K$ is directly related to the synthesis, transport and accumulation of sugars, allowing the fruit to grow and achieve its quality (Ganeshamurthy et al., 2011).

Other research on these species under different management conditions reported higher $\mathrm{K}$ variations compared to the levels observed in this work, highlighting the importance of potassium fertilization to increasing mineral nutrient levels in fruits. In pitayas produced by $H$. polyrhizus, the levels were $12.6 \mathrm{~g} \mathrm{~kg}^{-1}$ (Cordeiro et al., 2015) in fruits harvested in Malaysia and $1.58 \mathrm{~g} \mathrm{~kg}^{-1}$ and $4.37 \mathrm{~g} \mathrm{~kg}^{-1}$ for fruits harvested in Australia (Nurul \& Asma, 2014).

The levels of $\mathrm{Ca}$ and $\mathrm{Mg}$ were higher in the fruits harvested in the plants that received the potassium fertilization. Ca levels in $\mathrm{H}$. undatus increased from 0.58 $\mathrm{g} \mathrm{kg}^{-1}$ to $0.96 \mathrm{~g} \mathrm{~kg}^{-1}$, and in $\mathrm{H}$. polyrhizus they increased from $0.65 \mathrm{~g} \mathrm{~kg}^{-1}$ to $1.03 \mathrm{~g} \mathrm{~kg}^{-1}$. The $\mathrm{Mg}$ levels ranged from $0.25 \mathrm{~g} \mathrm{~kg}^{-1}$ to $0.78 \mathrm{~g} \mathrm{~kg}^{-1}$ in fruits of $\mathrm{H}$. undatus and $0.25 \mathrm{~g}$ $\mathrm{kg}^{-1}$ to $0.28 \mathrm{~g} \mathrm{~kg}^{-1}$ in fruit of $\mathrm{H}$. polyrhizus when the plants received the 0 and $200 \mathrm{~g}$ dose of $\mathrm{K}_{2} \mathrm{O}$, respectively (Table 1). Although the availability of $K$ in high concentrations in the soil solution may interfere with the absorption of $\mathrm{Ca}$ and $\mathrm{Mg}$ due to competition between these cations, these results do not indicate that this occurred in the doses tested. The results also indicate that the nutrient levels were higher in fruits in the third productive cycle probably because the soil levels were higher.

For the quality of the pitayas, the results are important considering that the Ca makes a fundamental role for fruits, because it affects its final quality and its storage capacity after harvest (Aular \& Natale, 2013).

The levels of N, P, B, CU and Zn were lower in fruits from plants that had the highest availability of $\mathrm{K}_{2} \mathrm{O}$ (Table 1). In the plants that were fertilized with the $200 \mathrm{~g}$ dose of $\mathrm{K}_{2} \mathrm{O}$ the lower nutrients levels observed can be attributed to the higher productivity of fruits and to the vegetative growth, occurring redistribution of these nutrients for a greater quantity of drains, nitrogen and phosphate fertilization was the same for all plants. However, with a higher availability of $\mathrm{K}$, productivity increased.

The observed results highlight the importance of balanced fertilization to produce nutrient-rich fruits. Differences in the nutrient availability of different areas and how orchards are managed help explain the different results reported for pitayas across related studies.

It is also worth mentioning that almost all of the nutrient-adjusted models were linear, showing an increase with the highest availability of $K$ in the soil. An exception was observed for $K$ in the species $H$. undatus during the fourth production cycle, possibly because the maximum productivity reached in this cycle of production was determined with the dose of $160 \mathrm{~g}$ of $\mathrm{K}_{2} \mathrm{O}$ per plant. However, this may be related to the increasing demand from plants of this species, which presents greater vegetative growth. Thus, some of the nutrients may have been directed to the emission of new sprouts, thus compromising fruit production. 
The results reported for the mineral composition of $\mathrm{H}$. polyrhizus pitayas fertilized with organic source presented similar results for $\mathrm{N}, 11.3 \mathrm{~g} \mathrm{~kg}^{-1}$ and $\mathrm{K}_{1} 12.6 \mathrm{~g} \mathrm{~kg}^{-1}$, and higher levels for $\mathrm{Ca}, 8 \mathrm{~g} \mathrm{~kg}^{-1}$. These mineral nutrients are found in the greatest concentration in the pitaya pulp (Cordeiro et al., 2015). These nutrient levels are higher than those reported by Nurul \& Asmah (2014) for pitayas from Australia and Malaysia.

The results demonstrate that $K$ fertilization increased the concentration of nutrients in the fruit which are important to human nutrition. However, it did not interfere in the export of Fe, which is one of the most important nutrients gained through food.

$\mathrm{K}$ was the nutrient exported most by the two pitaya species (Tables 2 and 3). With increasing productivity due to potassium fertilization and dry matter levels of the pitayas, there was an increase in the export of this nutrient, from $8.49 \mathrm{~kg}$ to $20.79 \mathrm{~kg}$ in plants fertilized with $200 \mathrm{~g} \mathrm{~K}_{2} \mathrm{O}$ and $1.56 \mathrm{~kg}$ to $14.9 \mathrm{~kg} \mathrm{~K}$ in those fertilized with $160 \mathrm{~g} \mathrm{~K}_{2} \mathrm{O}$. There was a mean of $2.3 \mathrm{~kg}$ to $2.4 \mathrm{~kg}$ per ton of fruit present for the $\mathrm{H}$. undatus species in the productive cycles evaluated (Table 2). Similar results were observed in $H$. polyrhizus, which ranged from $10.52 \mathrm{~kg}$ to $17.73 \mathrm{~kg}$ and from $2.53 \mathrm{~kg}$ to $15.89 \mathrm{~kg} \mathrm{~K}$ per plant for the $0 \mathrm{~g} \mathrm{~K}_{2} \mathrm{O}$ and $200 \mathrm{~g} \mathrm{~K}_{2} \mathrm{O}$ treatments, respectively, with a mean of 2 $\mathrm{kg}$ to $2.2 \mathrm{~kg} \mathrm{~K}$ per ton of fruit (Table 3). Although the two species studied exported different quantities of nutrients, in reality due to productivity levels, as evidence by the average per ton, were quite similar.

These results highlight the importance of fertilization, as a greater amount of mineral nutrients are withdrawn from the plant during the fruit harvest. More attention should be given to the replacement of nutrients such as $\mathrm{K}$ that are used and exported in large quantities. Similar results for $K$, which is among the most exported nutrients, have been reported for other fruit species. Plants' demand for $K$ is due to its importance in several biochemical and physiological processes (Ganeshamurthy et al., 201 1; IPI, 2013).

For the other nutrients, an increase in the quantity exported due to greater productivity was also observed with potassium fertilization, compared to exports of those that did not receive potassium fertilization (Tables 2 and 3). The export of $\mathrm{N}$ increased from $10.77 \mathrm{~kg}$ to $16.96 \mathrm{~kg}$ and from $1.87 \mathrm{~kg} \mathrm{~N}$ to $11.84 \mathrm{~kg}$, in the species $\mathrm{H}$. undatus and for $\mathrm{H}$. polyrhizus from $7.8 \mathrm{~kg}$ to $14.7 \mathrm{~kg}$ and from 3.1 $\mathrm{kg}$ to $9.2 \mathrm{~kg}$ of $\mathrm{N}$ (Tables 2 and 3). For the pitaya species $H$. undatus and $H$. polyrhizus, $1.2 \mathrm{~kg}$ to $1.9 \mathrm{~kg}$ of $\mathrm{N}$, the second-most exported nutrient, was needed to produce one ton. $\mathrm{N}$ participates in several processes, such as photosynthesis, the formation of proteins, nucleic acids and vitamins, and cell differentiation (Malavolta, 2006).

The export of $\mathrm{Ca}$ in the fruits of $\mathrm{H}$. undatus increased from $0.45 \mathrm{~kg}$ to $1.2 \mathrm{~kg}$ and $0.12 \mathrm{~kg}$ to $0.78 \mathrm{~kg}$. In $\mathrm{H}$. polyrhizus pitayas, export increased from $0.63 \mathrm{~kg}$ to $1.0 \mathrm{~kg}$ and from $0.25 \mathrm{~kg}$ to $1.03 \mathrm{~kg}$. Similarly, the $\mathrm{Mg}$ increased from $0.18 \mathrm{~kg}$ to $0.39 \mathrm{~kg}$ and from $0.04 \mathrm{~kg}$ to 0.25 $\mathrm{kg}$ in fruits of the $\mathrm{H}$. undatus species $\mathrm{In} \mathrm{H}$. polyrhizus $\mathrm{Mg}$ also increased, from $0.23 \mathrm{~kg}$ to $0.41 \mathrm{~kg}$ and $0.08 \mathrm{~kg}$ to 0.85 $\mathrm{kg}$. Exports of $P$ increased from $1.19 \mathrm{~kg}$ to $2.18 \mathrm{~kg}$ and from $0.29 \mathrm{~kg}$ to $1.07 \mathrm{~kg}$ in $\mathrm{H}$. undatus. In H. polyrhizus, P exported increased from $1.03 \mathrm{~kg}$ to $1.81 \mathrm{~kg}$ and from $0.44 \mathrm{~kg}$ to 1.18 $\mathrm{kg}$, in the third and fourth production cycles, respectively (Tables 2 and 3 ).

In view of the observed results, the order of macronutrients exported in pitaya fruits fertilized with doses between $160 \mathrm{~g}$ and $200 \mathrm{~g}$ of $\mathrm{K}_{2} \mathrm{O}$ per plant was $\mathrm{K}>\mathrm{N}>\mathrm{P}>\mathrm{Ca}>\mathrm{Mg}$ (Tables 2 and 3). This export order may vary across orchards that use different management and sources in the fertilization.

One of the variables of relevance to managing the fertilization of the plants is the age of the orchards. Considering the formation of the orchards, the demand is increasing, as noted in the present work. In the third cycle of production, the amount of nutrients in the fruits of the species two was higher than in the fourth cycle, which was under the same fertilization management regime, suggesting that the plants' demand for nutrients to support vegetative growth increased, as productivity did not change in the fourth cycle (Tables 2 and 3).

Regarding micronutrient exports, a higher amount was exported by the fruits of the plants fertilized with $\mathrm{K}_{2} \mathrm{O}$. Due to the higher productivity of these plants, the quantities per ton of fruit ranged from $0.47 \mathrm{~g}$ to $0.81 \mathrm{~g}$ of $\mathrm{B}$, from $2.8 \mathrm{~g}$ to $3.5 \mathrm{~g}$ of $\mathrm{Cu}$, from $4.6 \mathrm{~g}$ to $19.1 \mathrm{~g}$ of $\mathrm{Mn}$, from $1.7 \mathrm{~g}$ to $13.8 \mathrm{~g}$ of $\mathrm{Zn}$ and from 3.5 to $6.1 \mathrm{~g}$ of Fe (Tables 2 and 3). Mn was most exported by the two species and, according to the calculated quantities, the export order was the same in the two species, $\mathrm{Mn}>\mathrm{Fe}>\mathrm{Cu}>\mathrm{Zn}>\mathrm{B}$.

Micronutrients are exported in smaller quantities than macronutrients, but in this experiment the quantities exported increased with potassium fertilization due to the higher productivity of the plants (Tables 2 and 3). When analyzing the nutrient values exported in the fruits of the plants that did not receive potassium fertilization, it is observed that the quantities of the third productive cycle are higher than those exported by the plants in the fourth cycle. This difference may have occurred due to the use of mineral nutrients by the now-larger plants.

The lowest amount of nutrients exported by 
fruits in the fourth productive cycle (Tables 2 and 3) may have occurred because the plants were all fertilized with the same quantities of nutrients. This indicates that the quantities should vary according to the age of the orchard. It is inferred, therefore, that pitaya, such as other fruit species, requires differentiated fertilization after the third crop so that it can realize its productive potential.

The export of nutrients in $H$. undatus and $H$. polyrhizus occurred in the order $\mathrm{K}>\mathrm{N}>\mathrm{P}>\mathrm{Ca}>\mathrm{Mg}$ and $\mathrm{Mn}>\mathrm{Fe}>\mathrm{Cu}>\mathrm{Zn}>\mathrm{B}$ (Tables 2 and 3 ). Thus, the two species of pitaya have similar nutritional requirements, enabling them to be managed under identical fertilization regimes. Information on nutrient export is important to managing fertilization effectively. The nutrients most exported by the fruits need to be replenished through fertilization to avoid soil exhaustion and plant deficiencies.

In order to suitable fertilize the orchards, other factors must be considered, since the nutrients are used and stored in other organs, such as leaves and roots. It is necessary to consider the reactions and the dynamics of the nutrients in the soil for the correct definition of fertilization (Malavolta et al., 1997).

The results indicate the need to replace nutrients exported in greater quantities, such as $\mathrm{K}$ and $\mathrm{N}$, helping to meet the nutritional demands of the plant, maintaining a high level of productivity and producing desired yields. With a lower availability of nutrients to plants, productivity can be reduced significantly, as observed in the plants that did not receive potassium fertilization (Tables 2 and $3)$.

Although the pitaya species show genetic differences and respond differently to fertilization, the results for the two species are similar in relation to nutrient demand. Management is critical to the successful production of high-quality fruits. Orchards of pitaya that are highly productivity require a greater quantity of nutrients, due to the greater export by the fruits.

The results of this research highlight the importance of studies focusing on potassium fertilization. In addition to being necessary for plant growth and development, $\mathrm{K}$ can easily lost from the soil via leaching. However, its indiscriminate use can inhibit the absorption of other nutrients and reduce fruit production and quality.

This work also serves to guide related research that aims to adapt fertilization management to the production of quality fruits, increase productivity and adequately replace nutrients that are exported by pitaya species.

\section{Acknowledgments}

The authors thank the Research Support Foundation of Minas Gerais State (FAPEMIG) and the Coordination of Superior Level Staff Improvement - Brazil (CAPES), for the financial support to this research.

\section{References}

Aular, J., Natale, W. 2013. Nutrição mineral e qualidade do fruto de algumas frutíferas tropicais: goiabeira, mangueira, bananeira e mamoeiro. Revista Brasileira de Fruticultura 35: 1214-1231.

Chakma, S.P., Harunor Rashid, A.S.M., Roy, S., Islam, M. 2014. Effect of NPK doses on the yield of dragon fruit (Hylocereus costaricensis [F.A.C. Weber] Britton \& Rose) in Chittagong Hill Tracts. American-Eurasian Journal of Agricultural and Environmental Sciences 14: 521-526.

Cordeiro, M.H.M., Silva, J.M., Mizobutsi, G.P., Mizobutsi, E.H., Mota, W.F. 2015. Caracterização física, química e nutricional da pitaia-rosa de polpa vermelha. Revista Brasileira de Fruticultura 37: 20-26.

Fernandes, D.R., Moreira, R.A., Cruz, M.C.M., Rabelo, J.M., Oliveira, J. 2018. Improvement of production and fruit quality of pitayas with potassium fertilization. Acta Scientiarum. Agronomy 40: 1-9.

IPI, International Potash institute. 2013. Potássio, o Elemento da Qualidade na Produção Agrícola. São Paulo, 38 p. https://www.ipipotash.org/udocs/419-kquality_booklet_ portuegese_web.pdf. <Access on 17 Dec. 2018>

Ganeshamurthy, N., Satisha, G., Prakash Patil, P. 2011. Potassium Nutrition on yield and quality of fruit crops with special emphasis on banana and grapes. Karnataka Journal of Agricultural Science 24: 29-38.

Jerônimo, M.C., Orsine, J.V.C., Borges, K.K., Novaes, M.R.C.G. 2015. Chemical and Physical-Chemical Properties, Antioxidant Activity and Fatty Acids Profile of Red Pitaya [Hylocereus Undatus (Haw.) Britton \& Rose] Grown In Brazil. Journal of Drug Metabolism \& Toxicology 6: 1-6.

Khalili, R.M.A., Norhayati, A.H., Rokiah, M.Y., Asmah, R., Nasir, M.T.M., Muskinah, M.S. 2006. Proximate composition and selected mineral determination in organically grown red pitaya (Hylocereus sp.). Journal Tropical Agriculture and Food Science. 34: 269-275.

Malavolta, E., Vitti, G.C., Oliveira, S.A. 1997. Avaliação do estado nutricional das plantas. Princípios e aplicações. 2.ed. Potafos, Piracicaba, Brazil. 319 p.

Malavolta, E. 2006. Manual de nutrição mineral de plantas. 1.ed. Agronomica Ceres, Piracicaba, Brazil, 638 p.

Mizrahi, Y. 2014. Vine-cacti pitayas - the new crops of the world. Revista Brasileira de Fruticultura 36: 124-138.

Moreira, R.A., Ramos, J.D., Araujo, N.A., Marques, V.B., Melo, P.C. 2012. Produtividade e teores de nutrientes em 
cladódios de pitaia vermelha utilizando-se adubação orgânica e granulado bioclástico. Revista Brasileira de Ciências Agrárias 7: 714-719.

Nobel, P., De La Barrera, E. 2002. Nitrogen relations for net $\mathrm{CO}_{2}$ uptake by the cultivated hemiepiphytic cactus, Hylocereus undatus. Scientia Horticulturae 96: 281-292.

Nurul, S.R., Asmah, R. 2014. Variability in nutritional composition and phytochemical properties of red pitaya (Hylocereus polyrhizus) from Malaysia and Australia. International Food Research Journal 21: 1689-1697.

Weiss, I., Raveh, E., Mizrahi, Y. 2009. Effects of $\mathrm{CO}_{2}-$ enrichment and fertilization regimes on net $\mathrm{CO}_{2}$ uptake and growth of Hylocereus undatus. Journal of the American Society Horticultural Science 134: 364-371.

Conflict of Interest Statement: The authors declare that the research was conducted in the absence of any commercial or financial relationships that could be construed as a potential conflict of interest.

All the contents of this journal, except where otherwise noted, is licensed under a Creative Commons Attribution License attribuition-type BY. 